\title{
"The innovation principles of economic model of the cadastral land valuation for business activity"
}

\begin{tabular}{|c|c|}
\hline AUTHORS & $\begin{array}{l}\text { Raisa Kozhukhivska id http://orcid.org/0000-0003-4066-4170 } \\
\text { Mikhail Shemyakin } \\
\text { Irina Udovenko } \\
\text { Natalia Verniuk }\end{array}$ \\
\hline ARTICLE INFO & $\begin{array}{l}\text { Raisa Kozhukhivska, Mikhail Shemyakin, Irina Udovenko and Natalia Verniuk } \\
\text { (2017). The innovation principles of economic model of the cadastral land } \\
\text { valuation for business activity. Problems and Perspectives in Management, } \\
\text { 15(3), 253-265. doi:10.21511/ppm.15(3-1).2017.09 }\end{array}$ \\
\hline DOI & http://dx.doi.org/10.21511/ppm.15(3-1).2017.09 \\
\hline RELEASED ON & Wednesday, 08 November 2017 \\
\hline RECEIVED ON & Friday, 01 September 2017 \\
\hline ACCEPTED ON & Friday, 22 September 2017 \\
\hline LICENSE & $\begin{array}{l}(\mathrm{cc}) \text { EY-NC } \\
\text { This work is licensed under a Creative Commons Attribution-NonCommercial } 4.0 \\
\text { International License }\end{array}$ \\
\hline JOURNAL & "Problems and Perspectives in Management" \\
\hline ISSN PRINT & $1727-7051$ \\
\hline ISSN ONLINE & $1810-5467$ \\
\hline PUBLISHER & LLC "Consulting Publishing Company "Business Perspectives" \\
\hline FOUNDER & LLC "Consulting Publishing Company "Business Perspectives" \\
\hline
\end{tabular}

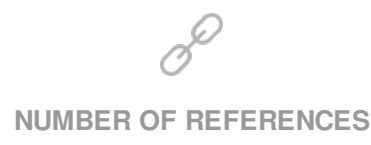

28

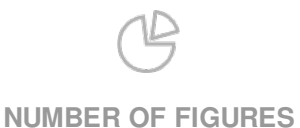

4
靖

NUMBER OF TABLES

2

(C) The author(s) 2022. This publication is an open access article. 


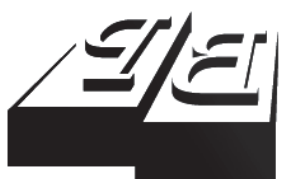

BUSINESS PERSPECTIVES

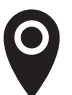

LLC “CPC "Business Perspectives” Hryhorii Skovoroda lane, 10, Sumy, 40022, Ukraine

www.businessperspectives.org

Received on: $1^{\text {st }}$ of September, 2017 Accepted on: 22 ${ }^{\text {nd }}$ of September, 2017

(C) Raisa Kozhukhivska, Mikhail Shemyakin, Irina Udovenko, Natalia Verniuk, 2017

Raisa Kozhukhivska, Ph.D. (Economics), Associate Professor, Uman National University of Horticulture, Ukraine.

Mikhail Shemyakin, Ph.D. (Agriculture), Associate Professor, Corresponding member of International Academy of ecology and life safety, Uman National University of Horticulture, Ukraine.

Irina Udovenko, Ph.D. (Economics), Associate Professor, Uman National University of Horticulture, Ukraine.

Natalia Verniuk, Ph.D. (Economics), Associate Professor, Uman National University of Horticulture, Ukraine.

\section{(ㄷ)(1) (8)}

This is an Open Access article, distributed under the terms of the Creative Commons Attribution-NonCommercial 4.0 International license, which permits re-use, distribution, and reproduction, provided the materials aren't used for commercial purposes and the original work is properly cited.
Raisa Kozhukhivska (Ukraine), Mikhail Shemyakin (Ukraine),

Irina Udovenko (Ukraine), Natalia Verniuk (Ukraine)

\section{THE INNOVATION PRINCIPLES OF ECONOMIC MODEL OF THE CADASTRAL LAND VALUATION FOR BUSINESS ACTIVITY}

\begin{abstract}
The aim of the article is to study, analyze and develop methods of the land cadastral valuation activity in the implementation of the procedure on revaluation of land facilities and operational adjustments, as well as to upgrade land evaluation results as a constantly functioning system for the effective planning of business activities for Cherkasy region in Ukraine. The cadastral evaluation must consider the market situations and trends the most. Frequency terms of the cadastral valuation for each of land categories and groups should be reviewed and individualized.
\end{abstract}

The article analyzes the mechanism and features of types of work on updating the state cadastral land valuation in populated localities in Ukraine, in particular of Cherkasy region, for the first time. The authors found that the main drawback of types of work on the economic model of cadastral land valuation in populated localities is the duration of time intervals between rounds of the revaluation that causes a rapid information aging. The reason for this situation is related to the financial support of types of work and their large scale.

The practical importance of research consists in conducting the revaluation (updating) of cadastral of land condition by Uman, as one of the most important objects of trade and consumer services in Cherkasy region in Ukraine. The cost of one square meter of such objects will increase, which will allow to increase the tax component in proportion and increasing profitability of budgets at the cluster level owing to actualization of the specific indicator of the cadastral value.
Keywords

JEL Classification evaluation, cadastre, cadastral valuation, land revaluation, populated localities, the share index of the cadastral value, the cluster

\section{INTRODUCTION}

Despite the considerable number of studies on various aspects of the economic model of the cadastral land valuation, currently, there is a problem in the research and development of a common methodology for the economic modeling of the cadastral land valuation for the business activity in Ukraine. The purpose of the article is to study, analyze and develop methods of land cadastral valuation activities when the procedure of the reevaluation, operational adjustments and updating of land evaluation results as a permanently functioning system for the business activity is conducted.

The cadastral land valuation is an important procedure in types of work on preparing information for the state cadastre of real estate. Thus, the main specific feature of urban lands is higher value of these areas in relation to other land categories by a few times. This is due to the high degree of urbanization and invested capital costs. 
The cadastral evaluation must consider the market situations and trends the most. Frequency terms of the cadastral valuation for each of land categories and groups should be reviewed and individualized. The updating term for lands in populated localities should be minimal and certainly economically justified in the context of the revaluation. The primary task of the real estate cadastre is to identify and determine each piece of real estate which is the object of taxation. Such unit can be a land plot, the land plot with a residential building or other buildings, a part of the house, such as flat, and so on (everything that the property tax can be accrued on).

Tax and rent play the most important role in the formation of budgets of all levels. In turn, they consist of the cadastral value of the property determined as a result of the state cadastral valuation. Thus, the main budget forming land category is lands of populated localities. The practical significance of updating results of the cadastral valuation is that it is the result of an increase in revenues of regional and local budgets through the effective use of property.

Updating results of the state cadastral land valuation, especially lands of populated localities, is a very important process. It requires a significant upgrading aimed at improving the quality of land appraisal types of work and adequately replenishing of budgets of all levels.

\section{LITERATURE REVIEW}

Theoretical and practical aspects of the economic model and development of areas are highlighted in the works. D. Davidson (1992) traces the de9 velopment and achievements of land evaluation during the 20th century. The most active period was between 1950 and around 1980 with the development of soil and land capability surveys, methodological advances initiated with the FAO Framework for Land Evaluation, and regional land resource assessments. Thus, there were considerable achievements in land evaluation by the early 1980s, and subsequently there have been important advances in the subject through the application of GIS, spatial analysis, modelling and fuzzy set algebra. Since the late 1990s there has been a phenomenal rise in interest in soil quality assessment. Considerable debate has focused on definition, and methods of assessment and monitoring. The latter part of this paper discusses the major challenges to the development and application of land evaluation. The inadequacy of much soil survey data in terms of variables, quality, spatial coverage and scale is emphasized. Also, there is a continuous need to highlight the centrality of land resource issues in any attempt to develop sustainable land use systems.

G. Larsson (2010) consider conceptually, land evaluation requires matching of the ecological and management requirements of relevant kinds of land use with land qualities, whilst taking local economic and social conditions into account. Land evaluation provides practical answers to such questions as "What other uses of land are physically possible and economically and socially relevant?", "What inputs are necessary to bring about a desired level of production?", and "What are the current land uses and what are the consequences if current management practices stay the same?".

The characteristics of regional socio-ecologicaleconomic systems as an object of modeling and forecasting were given on the basis of the generalization of the theory and practice of economy, the placement of productive forces and the regional economy were zoning by A. Sukhorukov and Y. Kharazishvili (2012). A new approach to the formation of a methodological basis for system modeling, forecasting and diagnosis of socioeconomic development of regions of Ukraine was developed in the works of A. Sukhorukov (2012). We carried out modeling and forecasting with the purpose of revealing the most actual problems and determining on this basis the main directions of the strategies of development of the regional economy (Y. Kharazishvili, 2012).

A. Hussen (2015) described the regional socio-, ecological-, economic systems as a method of modeling and forecasting based on a generalization of the theory and practice of economic zoning 
and regional economics. Methodological aspects of estimation of land and land relations, peculiarities of legislative regulation of normative monetary valuation of agricultural land and land of settlements in order to identify existing problems in assessing and determining the required order of its implementation are explored by V. Pavlova, L. Gonchar, R. Gubarev (2011).

In researches, I. Mykhasuk on the basis of the land cadastre and the further formation, and B. Kosovich (2002) considered the issues of land reform in Ukraine, state regulation of land relations of the agricultural and urban land market; revealed the legal bases of land relations in settlements; the prospects of development of post-reform land use, problems of regulation of rental relations.

Every business entity and, in particular, the state, are interested in conducting an objective monetary assessment that will take into account a set of scientifically based factors which adapted to modern conditions, according to O. Shtaher (2010). Current methods have certain disadvantage, which, of course, has a negative impact on the development of the land market and reduces the interest of landowners and land users in raising the rates of its status. O. Shtaher (2010) researched the principles of land evaluation, made an analysis of factors that significantly affect the calculation of value.

M. Malashevskyi (2016) considered some aspects of the formation of the land market in Ukraine,

researched the real estate market and analyzed the investment attractiveness of land plots in various territorial zones of the city. I. Perovych (2013) proposed to introduce the definition of "administration" as an instrument of effective and rational use of land resources for the future in the practice of land relations. An important effective tool in this case is the land cadastre as a registration and information system, which contains quantitative and qualitative indicators of land and their legal status (I. Perovych, 2013).

V. Baumane (2013) believes that the model of cadastral assessment of land can be improved by integrating the model of land valuation, as well as in cases where in the yard there are not only residential buildings but also non-residential, due to improved data in information systems and integration into the model of new indicators that will allow to obtain a more objective cadastral value, as well as a more objective real estate tax. N. Kukharuk, L. Martsynevskaia, A. Mytriaikyna (2011) believes that the primary task of the real estate cadastre is to identify and designate each unit of real estate representing the object of taxation. This unit can be a land plot, land with a house or other buildings. According to (N. Kukharuk et al., 2011) the tax and rent are made up of the cadastral value of real estate, which is determined as a result of the state cadastral valuation.

However, the issues of methodological aspects of the economic model of the cadastral land valuation for the business activity at present are scarcely explored.

\section{DATA AND METHODS}

During the study, methods of spatial analysis were used to determine the influence of the dominant factors in the value of land, which are based on the existing legislative and normative land valuation base. The formulae for calculating of the levels of the indexes of certain prevailing factors and the integrated land value index for a particular district of the settlement were derived using the methods of mathematical analysis.

Normative monetary valuation of the land of settlements requires information about factors that have a significant impact on the value of the territory. For this aim, from an entire set of factors, experts determine the prevailing factors and then determine the levels of influence of these factors on the general integrated index of value of land.

The procedure for determining the levels of the indexes of the prevailing factors, as well as the integrated index of the value of land, are the most labor-intensive processes in land valuation activity. In view of this, mathematical dependencies are proposed that simplify the process of calculating the level of the indexes of the prevailing factors, the complex index of the value of the land of the individual regions and the settlement as a whole. 
Methodological aspects of the land cadastral valuation activity, organizational basis of work on the revaluation of lands and types of updating (massscale, complete) are considered when there is a procedure of revaluation, operational adjustments and updating of evaluation results of lands as a permanently functioning system.

The first work on the state cadastral land valuation in populated localities of the region started in 2003. The evaluation was conducted by Main Department of State Geographical Cadastre in Cherkasy region and SE "Cherkasy Scientific Research and Design Institute of Land Management" in 855 populated localities of the region on a total area of 20.9 thousand $\mathrm{km}^{2}$ (The State Administration of Geological Cadastre in Cherkasy region, 2016; The Department of Lands Cherkassy region, 2016).

Reporting materials include specific indicators of the cadastral land value in populated localities with the number "before" and "over" 10,000 peot " ple defined by the types of functional land use. The second round of the mass-scale evaluation on updating its results was held within the activities of the Program "Creating urban cadastre Cherkasy region 2015-2017 years". The third round will be in 2018-2020.

According to the results of the competition held on 22 August, 2010, the customer - The State Administration of Geological Cadastre in Cherkasy region and The Department of Lands Cherkassy region concluded a contract (as of 30 August, 2010 No. 223) on the implementation of the new state cadastral land valuation in populated localities of the region. Financing of the ap- praisal work was conducted at the expense of the regional budget in the amount of UAH 3.5 million and at the expense of budgets of local entities (UAH 7.3 million).

The results of the state cadastral land valuation in populated localities of Cherkasy region were approved by Resolution of Main Department of State Land Committee in Cherkasy region on 24 April, 2011, No. 101-PP and entered into force on 1 January, 2012. In the reporting year, 4258746 land plots in populated localities are included in the electronic database by cadastral districts of the region from the evaluation description of data on economic characteristics. Thus, a mass-scale revaluation of lands that is the updated information about evaluation facilities which change is caused by the dynamics of the market was carried out.

The evaluation of the cadastral value of lands in populated localities of the region was done in accordance with Article 13 of the Law of Ukraine "On Land Valuation", by Methods of normative monetary value of non-agricultural lands (except settlements lands) approved by the Cabinet of Ministers of Ukraine of 23 November, 2011, No. 1278.

\subsection{Data sample}

According to methods of the normative monetary evaluation of lands, types of work on the state cadastral valuation were carried out by two production lines (PL) (Figure 1). According to PL 1, the calculation of the cadastral value of land plots in populated localities with a population of 10,000 people or more was carried out. There are 14 such populated localities. According to PL 2, the calcu-

\section{APPRAISAL WORK ON THE STATE CADASTRAL VALUATION}

According to Production Line 1 (PL), (the land valuation in populated localities with a population of 10,000 people and more)
According to Production Line 2 (PL), (the land valuation in populated localities with a population of less than 10,000 people

Figure 1. Implementation of the state cadastral land valuation* 
lation of the cadastral value of land plots was carried out in small towns, villages and rural settlements with a population of less than 10,000 people.

Implementation of the cadastral land valuation by the methodology of regulatory monetary value of non-agricultural lands (except lands of populated localities) ensures compliance with evaluation results by districts. The work was done according to the terms of reference of the contract.

Methods of data processing algorithms allow to monitor the market value of lands and real estate, constantly updating the change indexes in land value, taking into account local pricing factors, receiving value of fixed pricing options that can be used to evaluate some specific land plots (About claim of Order the state land cadastre, 2012).

Based on the theory and practice of econometric modeling, the following principles were used:

1) use of factors that take into account the specifics of Cherkasy region;

2) calculability of cost factor values for each appraisal object;

3) partial dependence of price (unit price) on this factor;

4) absence of factors that duplicate information;

5) limited number of factors $\mathrm{k}$ on the available market information in accordance with the fundamental provisions of the mathematical statistics:

$$
k \leq \frac{(n-6)}{6},
$$

where $n$ - sample size;

6) completeness of chosen factors to prepare a qualitative regression model that adequately reflects the market value of appraisal objects (Indexation of normative monetary value of land, 2010).

The statistical analysis was carried out to determine the reliability of the collected market data. As a result of the correlation and regression analysis of the available market information based on these principles, the cost factors for each type of land plots of the permitted use were identified.
Thus, in Cherkasy, the following factors were:

1) Land area in square meters;

2) Distance to the city center in meters;

3) Distance to the recreation area in meters;

4) Distance to industrial zones in meters;

5) Distance to major highways in meters;

6) Territorial zoning.

In Cherkasy region the determining cost factors were identified:

1) Land area in square meters;

2) Distance to Cherkasy city in meters;

3) Distance to the administrative center in kilometers (for urban areas) or the distance to the district center in kilometers (for rural areas);

4) Number of population;

5) Territorial division into four zones.

\subsection{Modelling approach}

The purpose of constructing models on calculation of the cadastral land value is to receive a statistically significant and qualitative model that allows to calculate the cost for each group of appraisal objects. The calculation model is the algom rithm for calculating the cadastral value based on regression analysis models.

The regression analysis model is an equation:

$$
Y=f\left(X_{1}, X_{2}, \ldots X_{n}\right),
$$

where $f\left(X_{1}, X_{2}, \ldots X_{n}\right)$, based on existing sample data by methods of mathematical statistics (The Land Code of Ukraine, 2001).

To assess the specific indicator of the cadastral value (SICV) of land plots, such regression models are used:

- $\quad$ linear $-Y=a_{0}+a_{1} X_{1}+\ldots+a_{n} X_{n}$;

- multiplicative consecutive $Y=a_{0} \cdot X_{l}^{a l} \ldots X_{n}^{a n}$;

- $\quad$ exponential $-Y=a_{0} e^{a_{1} x_{1}+\ldots+a_{n} x_{n}}$,

where $Y$ is a dependent variable (SICV): 
$X_{1}, \ldots, X_{n}$ - dependence factors of land plots;

$a_{0}, a_{1}, \ldots, a_{n}-$ model coefficients (Kukharuk et al., 2011).

Sample information, given that these models are based, is formed by all objects (objects-analogues) with a certain market value.

Based on the statistical analysis of market data, the information about objects-analogues with sample indicators of the market value and/or in the values of value factors is determined and eliminated, consistency and interpretability of market information used to develop the regression model of calculation are provided, the sample representativeness is tested and cost factors for developing statistical models are chosen.

Usually, sampling parameters are defined in several stages. First, lower and upper value limits are found based on the analysis of the market. After that, the sample is given to the requirement of representativeness. One of these requirements is an even distribution of objectsanalogues in the price range (The State Statistics Committee of Ukraine, 2016).

Also, in the process of modeling there can be objects with false market information - such items are defined as the sample. Also, the presence of the contradictory information in the sample leads to the elimination of certain objects-analogues. As a result of the analysis of market ina formation, we have identified the following features: the limited number of objects-analogues from each type of permitted use, compared with the total number of objects of evaluation; value ranges of value factors of objects-analogues do not cover the relevant range of evaluation objects.

These features give additional restrictions to the choice of the type of the regression model: calculating the values of the dependent variable, regardless of the sample data (extrapolation). In case of extrapolation the linear regression model often makes the slightest error compared with power and exponential models. Therefore, it is the best indicator for evaluating a specific nature of the cadastral land value.
The practical application of the classical linear regression involves performing a number of requirements that determine the quality of the model:

1) the model should be significant;

2) the coefficient of determination must be at least 0.7 ;

3) there is no multi collinearity;

4) residual values should have a normal distribution.

The quality of the model is determined by the Fisher criterion to use statistical data:

$$
F=\frac{(N-m-1) \cdot R^{2}}{m \cdot\left(1-R^{2}\right)}
$$

where $N$ is a number of objects in the sample; $\mathrm{m}$ is a number of cost factors used in the model.

The model is considered perfect if found value $\mathrm{F}$ exceeds limiting value $F_{a, m, N-m-1}$ at a given level $a=0.05$. In statistical packages there are statistical value $\mathrm{F}$ and significance (probability that $\mathrm{F}$ value does not exceed the threshold requirement $\left.F_{a, m, N-m-1}\right)$.

The coefficient of determination is calculated using the formula:

$$
R^{2}=1-\frac{\sum_{i=1}^{n}\left(Y_{l}-Y\right)^{-2}}{\sum_{i=1}^{n}\left(Y_{1}-Y_{c p}\right)^{2}},
$$

where $Y_{l}$ is the model magnitude estimation; $Y_{c p}$ is an average market land value in the sample. Multicollinearity means that between regressors (cost factors) is a high degree of correlation (among existing factors there are "extra" factors).

The most accurate indicator of the multicollinearity presence is the increasing dispersion coefficient $\operatorname{VIF}\left(b_{j}\right)$ which is given by:

$$
\operatorname{VIF}\left(b_{j}\right)=\frac{1}{1-R_{j}^{2}},
$$


where $R_{j}^{2}$ is the coefficient of the multiple determination in the regression of $j$ variable to other variables. "Bad" VIF values are considered from 4 or more.

Distribution of residual values can be determined using P-P and Q-Q diagrams and various statistical criteria. In the work, P-P diagram and Kolmogorov \& Smirnov criterion are used.

In statistical packages the observed value and asymptotic significance (probability that the observed value does not exceed the limit one) are specified.

The algorithm for calculating the cadastral value of assessment objects is the application of the method of the average cost factor to the developed regression model (The Land Code of Ukraine: scientific practical commentary, 2008).

The method of the average cost factor is that when $a_{j}\left(x_{j}-x_{j}\right)<0$ the value of $x_{j}$ factor can be replaced by the average value of this factor from the sample for continuous factors. As a result of the study, econometric models for calculating the cadastral value were developed and the quality of models was analyzed for each group of land plots (appraisal objects) in Cherkasy region.

Cherkasy Centre of Technical Inventory and Land Management carried out the current cadastral valuation of all land plots of the permitted use in Cherkasy region through these models.

The coefficient of indexing normative monetary value of lands calculated in accordance with paragraph 2 of Article 289 of the Tax Code of Ukraine as of January 1, 2016 is 1.433 . According to it, the normative monetary value of lands in populated localities and other non-agricultural lands is indexed. The coefficient of indexing normative moni etary value of lands is used cumulatively depending on the date of the normative monetary value of lands. The coefficients of indexing normative monetary value of lands were 1.0 in 2010, 1.0 in 2011, 1.0 in 2012, 1.0 in 2013, 1.249 in 2014 and 1.433 in 2015.

Let us consider the calculation of indexing normative monetary value of lands by the example of one of the settlements. It is Uman city for which the land assessment was carried out by the first production line.

\section{RESULTS AND DISCUSSION}

The results of assessment are the specific indicators of the land cadastral value and specific indicators of the land cadastral value of the cadastral quarter by types of functional use within populated localities (Rakoid, 2008). Carrying out research work on the state cadastral land valuation in populated localities of Cherkasy region was on the basis of existing regulations. Calculations were made using MS Office and IBM SPSS Statistics 19.

The aim of the research was to study and choose approaches, methods and patterns to determine the cadastral land value in populated localities of Cherkasy region as of 1 January, 2016 in the context of such land types of the permitted use:

1) land plots intended for placement of retail, catering and consumer service facilities;

2) land plots intended to accommodate the administrative buildings, buildings of social security, physical education and sport, culture, art and religion;

There were the following activities:

1) determination and justifying calculations of pricing factors on the value of land plots for each type of land plots of the permitted use based on the analysis of the information about the real estate market in cherkasy region, accounting characteristics of land plots and a list of cost factors provided by the customer;

2) econometric models on the calculation of the cadastral value for each group of land plots (appraisal objects);

3) analysis of the quality of the models.

The approximate list of pricing factors of the value of land plots is proposed in the Resolution of Cabinet of Ministers of Ukraine dated on October 17, 2012 No. 1051 "On approval of the State Land Cadastre". 


\subsection{Special conditions for SICV calculating in Uman}

1. The functional and planning structure of Uman as a few receptors has been taken from the Report of Land Valuation of Uman in 2010. The decision was agreed at the interdepartmental commission. The report on land assessment in populated localities of Cherkasy region was in accordance with the AR catalog (Address Register) received from Main Department of State Geographical Cadastre in Cherkasy region.

2. The range and size of zones of influence for objects of pricing factors were determined at the rate of 15-20 minute availability. This is consistent with the planning of the populated locality. The range and size of zones of influence were agreed with The Interdepartmental Committee on Review of Assessment Results and Work Organization in Uman.

3. In Uman, there is a housing market of multistorey and private house building and lands for garages. Therefore, three basic constants were calculated for the multi-storey building, the private house building and lands for garages and parking lots.

4. The calculation of the basic constant for the multi-storey building was carried out by the following output data:

- the cost of a new construction is $8117 \mathrm{UAH} /$ $\mathrm{m}^{2}$ for Uman district (Letter of Territorial Authority State Statistics Service of Cherkasy region, No. 45-78/01 as of 10 June, 2015;

- depreciation is 0.1 (chosen by the checklist for impairment of buildings and facilities in percent of the construction cost), the useful life of buildings defined from the information in agreements;

- housing density is 0.88 ;

- the basic indicator is determined by the normalizing one.
5. The calculation of the basic constant for the private house building was carried out by the following output data:

- the cost of a new construction is 0 (used land transactions);

- depreciation is 0 ;

- housing density is 1 .

6. The calculation of the basic constant for lands for garages and parking lots was:

- the cost of a new construction is 0 (used land transactions);

- depreciation is 0 ;

- housing density is 1 .

7. There was a group of experts of 10 people to calculate the expert component. After questionnaires and analyzing expert consideration coefficient, questionnaires with numbers 9,10 were rejected. The average value of appraisal indicators was calculated by $1,2,3,4,5,6,7$ and 8 questionnaires.

8. SICV calculating was by classification of use.

Here are the results of the land revaluation in Uman (Figure 2). Figure 2 shows the dynamics of values of marginal data of the cadastral value in the absolute value, as well as trends of rising land cost in the land cadastral appraisal update. The chart shows that the lowest values of marginal data in the absolute value are for lands of such types of the functional use: lands for the private house building, lands of cottage and garden associations of citizens, lands for health and recreational purposes, lands of agricultural use, lands of agricultural use and lands for isolated water bodies.

The range of variation of results of marginal data of the land value in 2010 was from $19.55 \mathrm{UAH} / \mathrm{m}^{2}$ (lands for isolated water bodies) to $601.5 \mathrm{UAH} / \mathrm{m}^{2}$ (lands for objects of trade, public catering, consumer services); in 2015 from $659.01 \mathrm{UAH} / \mathrm{m}^{2}$ (lands of garages and parking lots) to $1615.1 \mathrm{UAH} / \mathrm{m}^{2}$ (lands for objects of trade, public catering, consumer services).

The largest increase in cost indicators after revaluation was of multi-storey buildings. This increase 


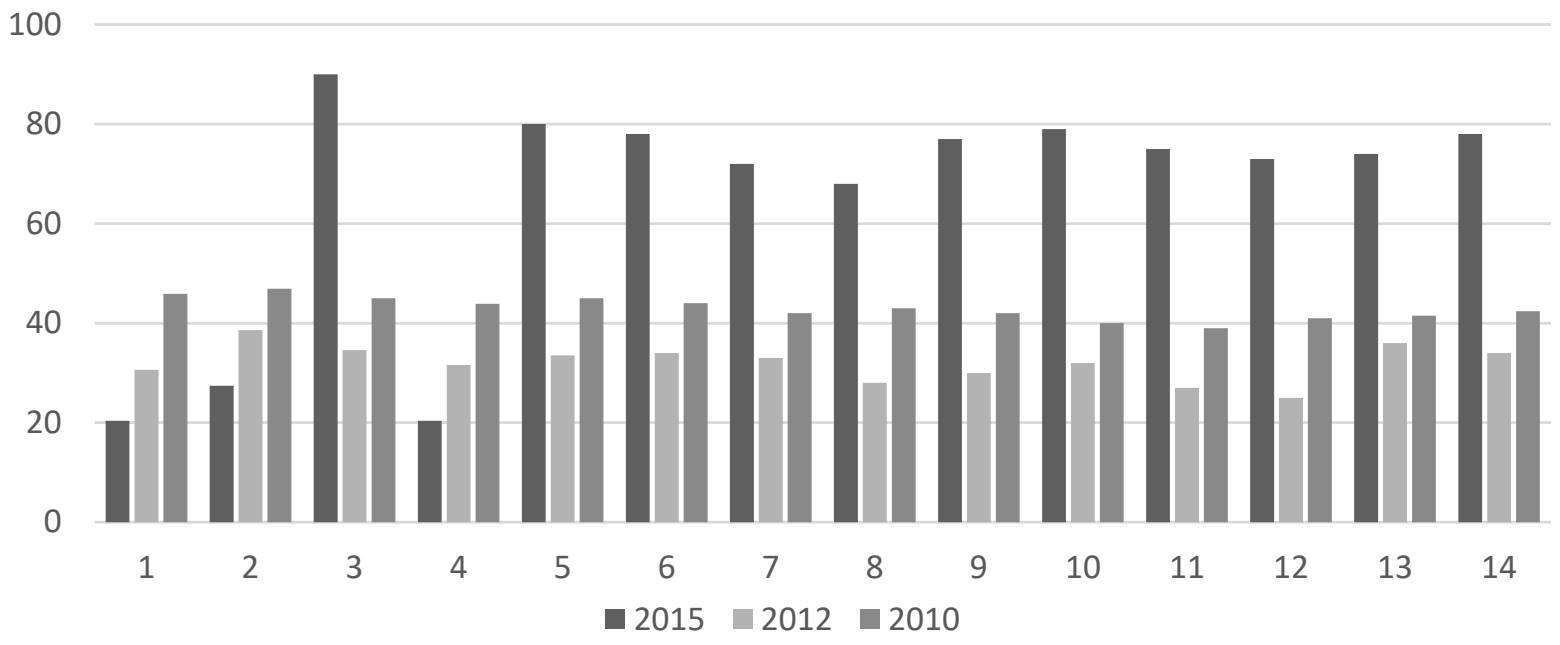

Notes: Explanation of symbols: 1 - lands for the multi-storey building; 2 - lands for the private house building; 3 - lands of cottage and garden associations of citizens; 4 - lands of garages and parking lots; 5 - lands for objects of trade, public catering, consumer services; 6 - lands for institutions and organizations of public education; 7 - lands for industrial facilities; 8 - lands for administrative-management and public objects; 9 - lands for military facilities; 10 - lands for health and recreational purposes; 11 - lands of agricultural use; 12 - lands of agricultural use in populated localities; 13 - lands for isolated water bodies; 14 - other lands of populated localities.

Figure 2. The share index of the cadastral value dynamics of Uman in land assessing

was 2.8 times. Also, this significant increase in land value will increase tax revenues proportionately.

Table 1 shows the increase in the updating types of the functional land use in the territory of Uman and Uman district.
Here are the results of updating (revaluation) of the cadastral land valuation in Uman of objects of trade, public catering and consumer services, one of the most important types of the functional land use in the value growth. Thus, due to the revaluation it is found that in 2010-2015 the functional and plan-

Table 1. Increase at updating the territory of Uman and Uman district

Source: calculated by the author on the basis of research.

\begin{tabular}{|c|c|}
\hline Types of the functional land use & $\begin{array}{c}\text { Increase } \\
\text { since } 2010 \text { to } 2015, \% \\
\end{array}$ \\
\hline Lands for the multi-storey building & 275 \\
\hline Lands for military facilities & 272 \\
\hline Lands for military facilities & 271 \\
\hline Lands for objects of trade, public catering and consumer services & 268 \\
\hline Other lands of populated localities & 268 \\
\hline Lands for institutions and organizations of public education & 267 \\
\hline Lands for administrative-management and public objects & 267 \\
\hline Lands for health and recreational purposes & 265 \\
\hline Lands of agricultural use & 258 \\
\hline Lands for forests & 246 \\
\hline Lands for isolated water bodies & 241 \\
\hline Lands of cottage and garden associations of citizens & 238 \\
\hline Lands for the private house building & 205 \\
\hline Lands of garages and parking lots & 138 \\
\hline The average value & 248.5 \\
\hline
\end{tabular}




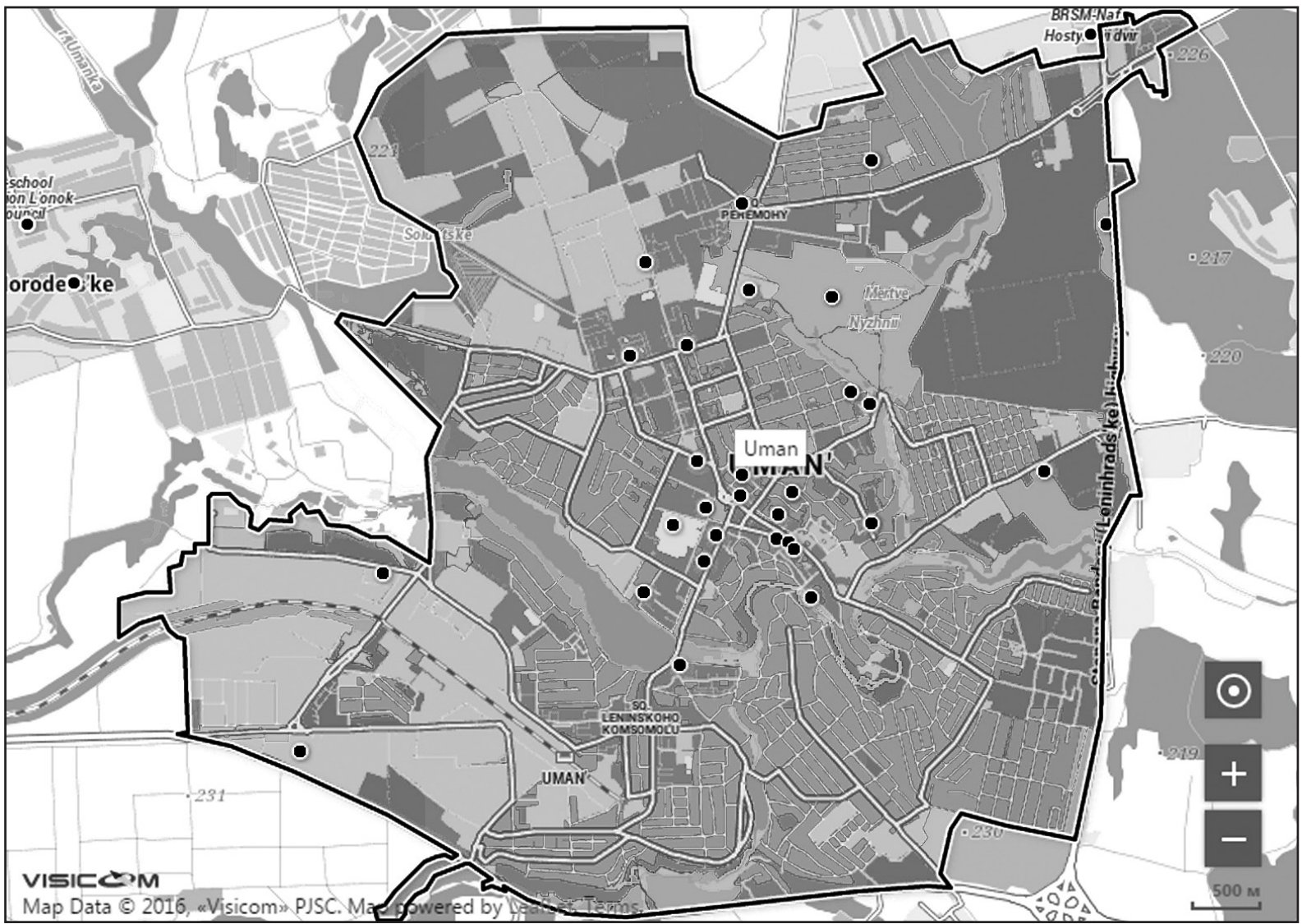

Figure 3. The schematic map of locating objects of trade, public catering and consumer services in Uman

ning structure did not undergo significant changes.

The schematic map (Figure 3) shows the location of 22 objects of trade and public catering facilities and 8 objects of consumer services in Uman. As, a result of updating, the cost per square meter of such facilities increased in 2.7 times allowing proportional increase and the tax component increasing profitability of budgets (Table 2).

The work sequence by the second production line involves the district clusterization. The informa- tion basis for the clusterization of administrative districts in the region was a typical number of statistical indicators by regions, according to the State Statistics Committee and Main Department of Statistics in Cherkasy region.

The area of the district and population are relatively constant. Other indicators are normed. If the normed indicator is less than one, such parameters in clusterization are not used. After the calculations, using software, we obtained the chart below (Figure 4).

Table 2. Results of updating in populated localities for objects of trade and consumer services in Uman

Source: author's calculations.

\begin{tabular}{l|c|c}
\hline \multicolumn{1}{c}{ Type of the functional land use } & $\begin{array}{c}\text { The marginal indicator of the cadastral } \\
\text { land value in populated localities } \\
\left(\mathbf{U A H} / \mathbf{m}^{2}\right) \text { in } \mathbf{2 0 1 0}\end{array}$ & $\begin{array}{c}\text { The marginal indicator of the } \\
\text { cadastral land value in populated } \\
\text { localities }\left(\mathbf{U A H} / \mathbf{m}^{2}\right)\end{array}$ \\
\hline $\begin{array}{l}\text { Lands } \mathbf{2 0 1 5} \\
\text { catering and consumer services }\end{array}$ & 601.50 & 1615.10 \\
\hline
\end{tabular}




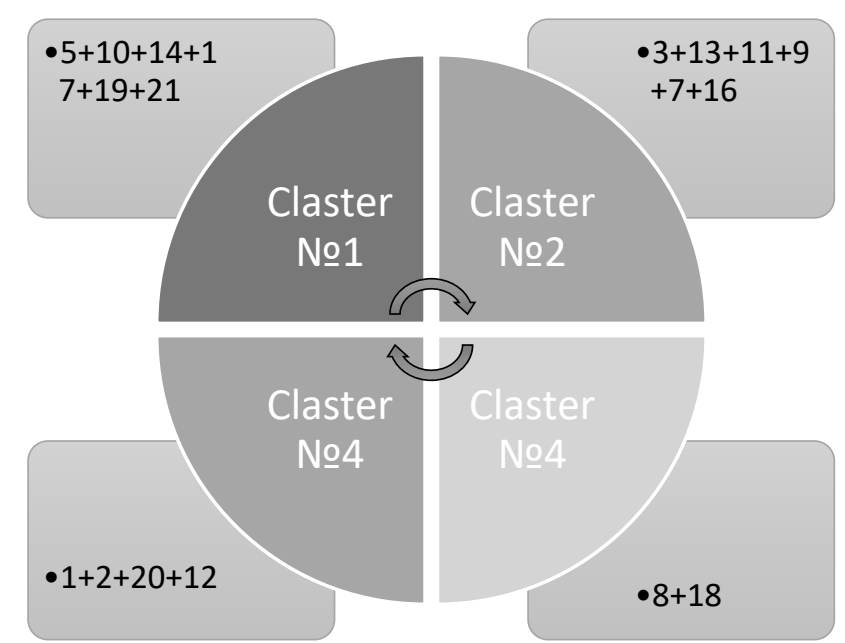

Figure 4. The result of the district clusterization in Cherkasy region

Visually, it is possible to distinguish district groups characterized by common values of factors. This suggests commonality of criteria that influence the pricing in each group. There are 4 such groups having common criteria. In group 4 , there is greater distance between objects but they are far from the other three groups. Considering that the objects of the fourth group have the developed economic potential and similar economic characteristics, they can be combined into one group. Thus, we get four clusters that were used in the calculations.

\subsection{Land revaluation results in Rodnykivka village}

Land revaluation results in Rodnykivka village of Uman district in the region (with a population of 3,385 people as of 2015) show an increase by types of the functional use on average by 2.21 times. It is a variant of the populated locality the population of which is less than 10 thousand people and therefore it was assessed by the second production line. It also proportionally increases the tax base by the updating results of the cadastral valuation.

The new methodological base of land revaluation in populated localities for future application includes Methodology of regulatory monetary value of non-agricultural lands (except lands of populated localities) approved by the Cabinet of Ministers of Ukraine of 23 November, 2011, No. 1278.

Thus, the socio-economic consequence of the application of results of the state cadastral land valuation for establishing tax land payments is the growth in increasing budgets.

\section{CONCLUSION}

As a result of our research, it is found that the main drawback of the work on updating results of the state cadastral land valuation is the duration of time intervals between revaluation rounds, because the information loses its relevance. The reason for this situation is related to the financial support and a large scale of types of the work.

The cadastral valuation must consider the market situations and trends. So, in our view, it is appropriate to update data at intervals of not less than 1 time per year (a half). Terms of frequency of the cadastral valuation for each of the categories and groups of lands should be reviewed and individualized as the existing terms "... at least once every 5 years and not more than once in 3 years ..." do not reflect the dya namics of an emerging market. For lands of populated localities, the updating term in the context of the revaluation should be minimal and certainly economically justified. 
To summarize, it should be noted that updating results of the state cadastral land valuation, especially lands of populated localities, is a very important process. It requires a significant upgrading aimed at improving the quality of land appraisal types of work and adequately replenishing of budgets of all levels.

\section{REFERENCES}

1. Baumane, V. (2010). Cadastral Valuation Models. Retrieved from http://vlp.com.ua/node/10798

2. Cabinet of Ministers of Ukraine (1995). Методика нормативної грошової оцінки земель сільськогосподарського призначення та населених пунктів [Metodyka normatyvnoi hroshovoi otsinky zemel silskohospodarskoho pryznachennia ta naselenykh punktiv] (Resolution, adopted on 23 March, 1995, 213). Retrieved from http://zakon4. rada.gov.ua/ laws/show/213-95$\% \mathrm{D} 0 \% \mathrm{BF}$

3. Cabinet of Ministers of Ukraine (2011). Методика нормативної грошової оцінки земель несільськогосподарського призначення (крім земель населених пунктів) [Metodyka normatyvnoi hroshovoi otsinky zemel nesilskohospodarskoho pryznachennia (krim zemel naselenykh punktiv)] (Resolution, adopted on 23 November, 2011, 1278). Retrieved from http://zakon1.rada. gov.ua/laws/show/1278-2011$\% \mathrm{D} 0 \% \mathrm{BF} /$ paran12\#n12

4. Cabinet of Ministers of Ukraine (2012). Про затвердження Порядку ведення Державного земельного кадастру [Pro zatverdzhennia Poriadku vedennia Derzhavnoho zemelnoho kadastru] (Draft Resolution, adopted on 17 October, 2012, 1051). Retrieved from http://zakon2.rada.gov.ua/ laws/show/1051-2012-\%D0\%BF

5. Cabinet of Ministers of Ukraine (2014). Про затвердження Методики нормативної грошової оцінки земель сільськогосподарського призначення [Pro zatverdzhennia Metodyky normatyvni hroshovoi otsinky zemel silskohospodarskoho pryznachennia] (Draft Resolution, adopted on 26 May, 2014, 621).
Retrieved from http://land.gov.ua/ zakonotvorcha-diialnist/621.html

6. Davidson, Donald A. (1992). The Evaluation of Land Resources (198 p.). Longman Scientific \& Technical: New York. Copublished in the U.S. with J. Wiley, 1992.

7. FAO (1976). A Framework for Land Evaluation. FAO Soils Bull., 32, FAO Rome, $72 \mathrm{p}$.

8. FAO (1996). Ecocrop. The Adaptability Level of the FAO Crop Environmental Requirements Database. Version 1.1. FAO/AGLS, 19 p. + Diskette.

9. Hussen, Ahmed M. (2005). Principles of environmental economics: economics, ecology and public policy. NY: Routledge. Retrieved from http:// s1.downloadmienphi.net/file/ downloadfile8/200/1375159.pdf

10. Kukharuk, N. S., Martsynevskaia, L. V., Mytriaikyna, A. M. (2011). Актуалізація результатів кадастрової оцінки земель населених пунктів [Aktualizatsiia rezultativ kadastrovoi otsinky zemel naselenykh punktiv]. $\mathrm{Na}$ uchni vedomosty. Seriia Yestestvenye nauky, 21(116), 150-160.

11. Larsson, Gerhard. (n.d.). Land Management as Public Policy. University Press of America.

12. Local Office of State Statistics Service of Cherkasy region (2015). Retrieved from http://www. ck.ukrstat.gov.ua

13. Main Department of Land Resources of Cherkasy region (2016). Retrieved from http:// cherkaska.land.gov.ua

14. Malashevskyi, M. (2016). Дослідження інвестиційної привабливості земельної ділянки комерційного використання [Doslidzhennia investytsiinoi pryvablyvosti zemelnoi dilianky komertsiinoho vykorystannia]. Retrieved from http://nbuv. gov.ua/UJRN/sdgn_2016_1_37

15. Ministry of Agrarian Policy and Food of Ukraine (2013). Порядок нормативної грошової оцінки земель несільськогосподарського призначення (крім земель населених пунктів) [Poriadok normatyvnoi hroshovoi otsinky zemel nesilskohospodarskoho pryznachennia (krim zemel naselenykh punktiv)] (Order, adopted on 22 August, 2013, 508). Retrieved from http://zakon1. rada.gov.ua/ laws/show/z1573-13\#n13

16. Mykhasiuk, I., Kosovych, B. (2002). Регулювання земельних відносин [Rehuliuvannia zemelnykh vidnosyn]. Lviv: LNU im. I. Franka.

17. Pavlova, V. A., Honchar, L. A., Hubariev, R. V. (2011) Методологічні аспекти нормативної грошової оцінки земель сільськогосподарського призначення та населених пунктів: сучасний стан та перспективи розвитку [Metodolohichni aspekty normatyvnoi hroshovoi otsinky zemel silskohospodarskoho pryznachennia ta naselenykh punktiv: suchasnyi stan ta perspektyvy rozvytku]. Retrieved from http://www.stattionline.org.ua/ekonom/75.html

18. Perovych, I. (n.d.). Кадастр як основа адміністрування земельних відносин [Kadastr yak osnova administruvannia zemelnykh vidnosyn]. Retrieved from http://nbuv.gov.ua/UJRN/ sdgn_2013_2_27

19. Rakoid, O. (2008).

Методичні рекомендації 3 комплексної оцінки земель сільськогосподарського призначення [Metodychni rekomendatsii z kompleksnoi otsinky 
zemel silskohospodarskoho pryznachennia]. Kiev: Lohos.

20. Shtaher, O. А. (2010). Грошова оцінка землі як інструмент управління [Hroshova otsinka zemli yak instrument upravlinnia]. Retrieved from http:// ea.donntu.edu.ua:8080/jspui/ handle/123456789/9466

21. State Administration of Geological Cadastre in Cherkasy region (2016). Retrieved from http:// www.chu.dkz.ck.ua

22. State Statistics Service of Ukraine (2016). Retrieved from http: // www.ukrstat.gov.ua

23. Sukhorukov, A. I., Kharazishvili, Yu. М. (2012). Моделювання та прогнозування соціальноекономічного розвитку регіонів України [Modeliuvannia ta proh- nozuvannia sotsialno-ekonomichnoho rozvytku rehioniv Ukrainy]. Retrieved from http://www.niss. gov.ua/content/articles/files/rozvyt_reg-77b7d.pdf

24. Supreme Council of Ukraine (2001). Земельний кодекс України [Zemelnyi kodeks Ukrainy] (adopted on 25 October 2001, 2768-III). Retrieved from http://zakon2.rada.gov.ua/laws/ show/2768-14

25. Supreme Council of Ukraine (2003). Про оцінку земель. Обов'язкове проведення грошової оцінки земельних ділянок [Pro otsinku zemel. Oboviazkove provedennia hroshovoi otsinky zemelnykh dilianok] (adopted on 11 December, 2003, 1378IV). Retrieved from http://zakon. rada.gov.ua/laws/show/1378-15
26. Supreme Council of Ukraine (2011). Податковий Кодекс України. Індексація нормативної грошової оцінки земель [Podatkovyi kodeks Ukrainy. Indeksatsiia normatyvnoi hroshovoi otsinky zemel] (adopted on 02 December, 2011, 2755-VI). Retrieved from http:// kodeksy.com.ua/podatkovij_ kodeks_ukraini/statja-289.htm

27. The Program "Creating urban cadastre of Cherkasy region for 2015-2017 years" (2015). Retrieved from http: // www.ckoda.gov.ua/docs/2015/01072015_ econom.pdf

28. Willy, Verheye H. (n.d.). Land evaluation. Retrieved from http:// www.eolss.net/sample-chapters/ c19/E1-05-02-00.pdf 